\title{
Ioan-Aurel Pop
}

Cultural Diffusion and Religious Reformation in Sixteenth-Century Transylvania:

How the Jesuits dealt with the Orthodox and Catholic Ideas. Lewiston: The Edwin Mellen Press, 2014 Pp. iii + 217. Pb \$149.95.

Ioan-Auel Pop, a leading expert in the early modern history of Transylvania, has taken a conspicuously even-handed and judicious approach to the complex and interwoven relationships among the various populations of the region. In this slender volume, he seeks first to inform the non-specialist about the environment of late medieval and Renaissance Transylvania into which the turmoil of the Protestant Reformation exploded in the sixteenth century. The unique constitutional arrangements of this principality, and its very early enshrinement of religious diversity are clearly set forth. Pop's monograph provides an introduction to the relevant secondary literature, but largely does not draw on primary sources, most conspicuously in the sections relating specifically to the Society of Jesus.

The author's second objective is critique the analyses that historians have hitherto employed to understand these events. Pop perceptively observes that a strictly ethnic-based approach to what he calls the "spiritual culture" of the region overlooks the strongly universalist values of the Catholic Church and the Renaissance, both of which profoundly influenced every aspect of Transylvanian culture. Confessional identity is deftly disentangled from local ethnic categories, and the shifting meaning of the term "nation" from the sixteenth to nineteenth centuries is addressed. These correctives are all the more important given the longstanding tendency of historiography of this region to be driven by nationalist concerns and anachronistic social categories. Pop also explores contemporaneous descriptions of the Romanian-speaking people of Transylvania, demonstrating that travelers recognized the language's connection to Latin.

The reader must wait until the last forty pages of the book to learn how Jesuits responded to the situation they found in Transylvania when they arrived in the 1570s. After a brief review of the reorganization of Catholic education following the Council of Trent, Pop details the creation of Jesuit schools in Cluj, Alba Iulia, and Oradea. Among the details he emphasizes is the role of Massimo Milanese, a Jesuit coadjutor temporalis or lay brother, who designed the collegium and residentia in Cluj. (Pop here places the word "brother" in parentheses without explanation, and later refers without a note to two "brothers" who were teaching in the Jesuit collegium in Cluj, so his understanding of the term is not clear.) Stephanus Arator (Szántó), the author of an anti-Qur'anic tract, and here described as a "ruffian" and an "antagonist" of Protestants, and 
the famed emissary and scholar Antonio Possevino were likewise influential players in the development of the Jesuit presence. In this section Pop relies in part on the recent scholarship of Aura Popa, "Activitatea misiunii iezuite din Transilvania 1579-1600," (Ph.D. thesis, Cluj-Napoca, 2007). We catch a glimpse of inter-ethnic squabbles among the Jesuits of Cluj, of the assembling of a significant library for their school, and of the disasters of plague and expulsion they faced. The paradox that the Jesuits' program, intended to strengthen a much weakened Catholic community, in fact contributed to the confessional diversity of Transylvania, is mentioned, but could have been probed more thoroughly. Pop hints at the factors involved when he points out that the Society's Transylvanian schools had many "heretics" as students, many of whom presumably did not convert to Catholicism, although elsewhere we read that students could be expelled from the Cluj collegium for following unorthodox doctrines.

The text suffers in a few places from minor stylistic infelicities and inaccurate lexical choices: a Jesuit residentia, for instance, is something very different from a "monastery." The choice of Wilna as a spelling for the city generally known as Vilnius or Wilno goes unexplained, and we read that Possevino had "an excellent relation" rather than "relationship" with Prince Stephen Báthory. "Jesuit Order" or "Company of Jesus" are used throughout instead of the more customary "Society of Jesus." Pop mentions an "Austrian takeover" of Transylvania in 1688, although the actual process took place between 1692 and 1696. Overall, however, this volume provides a lucid and fair-minded introduction to a time and place that has long deserved such treatment.

Paul Shore

University of Regina

shorep@brandonu.ca

DOI 10.1163/22141332-00203005-09 